\title{
POLISH OPINION WEEKLIES ABOUT BREXIT IN 2015 AND 2016
}

Marta JAS-KOZIARKIEWICZ, PhD

Assistant Professor, University of Warsaw, Faculty of Political Science and International

Studies, Poland

martajas@uw.edu.pl

\begin{abstract}
The aim of the article is to define the way in which Brexit referendum is presented by six Polish opinion weeklies (in 2015 and 2016) with the highest level of sales in 2015 and 2016 (Do Rzeczy, Gazeta Polska, Gość Niedzielny, Newsweek, Polityka, W Sieci). The study was prepared using qualitative content analysis. In the course of the analysis, answers were searched for questions concerning the following issues: the causes of Brexit indicated in articles, its consequences for the international arena, Poland and the European Union itself, and its assessment in the analysed weeklies. The research proved the connection between the assessment of this event in the weeklies and their political affiliations. This correlation can be seen, for example, in the editorial boards' stance towards Brexit, which was positive in right-wing titles (Do Rzeczy, Gazeta Polska, Gość Niedzielny, W Sieci) and negative in the magazines supporting Civic Platform (Polityka, Newsweek). However, no significant differences were found as regards the causes and effects of Brexit identified by the editorial boards. Regardless of political affiliations, journalistic materials indicated the same main reasons and the most important consequences of Britain's leaving the European Union. However, they were hierarchised differently and assigned a different rank.
\end{abstract}

Keywords: referendum, European Union, Polish opinion weeklies, Brexit, content analysis.

\section{Introduction}

The vote on the UK's stay in the EU in 2016 was one of the most important events for the European integration process from the beginning of the Communities. The nationwide referendum on integration was not anything new - by 2016 nearly 60 had been conducted (Musiał-Karg, 2016, 
p. 79). However, the preceding debate, the result of the referendum, and above all the consequences of the British decision made EU face the need to take action to change the organisation itself. The uniqueness of the event is related to the fact that so far none of the Member States has decided to leave the EU.

The final decision of the British interested all Europe, culminating in June, the month of the referendum (Europe Direct, 2016, p. 13) ${ }^{1}$. The significance of this topic can be demonstrated by the fact that in the majority of the articles analysed herein (with the exception of $W$ Sieci ${ }^{2}$ ) it was on the cover.

The article presents the results of the author's own research concerning the presentation of Brexit and the attitude taken by Polish opinion weeklies towards it. The introduction to the discussion is the part about the methodology of the research. The research problem selected for the analysis required supplementing it with information on the opinion weeklies market in Poland. This characteristics provided the context necessary to understand the subject. The following parts of the article present the results of the qualitative content analysis, which allowed to determine the reasons and consequences of Brexit indicated by the editorial boards, as well as to determine the attitude of the magazines towards it.

\section{Methodological assumptions}

The purpose of the paper is to determine the presentation of Brexit by Polish weeklies. In the course of the analysis, answers to the following research questions were sought:

- what reasons for Brexit were indicated in the articles?

- what consequences of Brexit are expected in the analysed titles?

- $\quad$ what is the relation of the magazines to Brexit?

The study was prepared using a qualitative content analysis - a research method allowing to determine what arguments, threads were taken, how the issues were presented and to what determinations the individual editors came (Kafel, 1969, 111) .

\footnotetext{
${ }^{1}$ For example information on the most popular topics of inquiries addressed to Europe Direct can be recalled. In June 2016, the theme of Britain's exit from the EU appeared most often.

2 Information about the referendum was on the cover, but it was not the subject of the issue.

${ }^{3}$ M. Kafel pointed out these qualities of qualitative content analysis: , it is not so much to explain to us the quantitative proportions of the press material, what to show what the newspaper and its creators wanted to communicate to their readers' (Kafel 1969: 111).
} 
The analysis comprised all issues of six Polish opinion weeklies with the highest sales in 2015 and 2016 (Do Rzeczy, Gazeta Polska, Gość Niedzielny, Newsweek, Polityka, W Sieci) ${ }^{4}-623$ issues in total. Investigating journalistic materials from opinion weeklies was justified by the fact that, alongside dailies, they play an important role in forming public opinion "due to their specific nature that is the analytical character of publications, enabling full presentation of a particular phenomenon or event and the widespread circulation of opinions expressed there in other media, including electronic ones”. (Stasiak-Jazukiewcz, 2015, 69-70).

Examined Items were selected on the basis of the subject matter criterion. We selected those in which Brexit was the leading topic. On this basis, 80 articles were qualified for the analysis (Table 1). A thematic categorization key was prepared for the needs of the study and the empirical material was developed using the ATLAS.ti program.

Table 1: Number of articles on Brexit in weeklies in 2015 and 2016

\begin{tabular}{|l|l|l|l|l|l|l|l|}
\hline & $\begin{array}{l}\text { Do } \\
\text { Rzeczy }\end{array}$ & $\begin{array}{l}\text { Gazeta } \\
\text { Polska }\end{array}$ & $\begin{array}{l}\text { Gość } \\
\text { Niedzielny }\end{array}$ & Newsweek & Polityka & W Sieci & Total \\
\hline $\begin{array}{l}\text { Number } \\
\text { of } \\
\text { articles }\end{array}$ & 17 & 14 & 13 & 12 & 16 & 18 & 80 \\
\hline $\begin{array}{l}\text { Number } \\
\text { of issues }\end{array}$ & 103 & 104 & 103 & 104 & 105 & 104 & 623 \\
\hline
\end{tabular}

Source: own study.

\section{The context of the research - a description of the opinion weeklies market in Poland}

The media market in Poland is relatively large, which makes it "pluralistic, more diversified and competitive". (Dobek-Ostrowska, 2015, 36). Its characteristic features are high competition between publishers, as well as significant politicisation observed in both private and public media (Reuters Institute, 2017, 84). A high degree of political polarisation is particularly noticeable in the case of opinion weeklies, whose editorial offices are ideologically involved. This is reflected in the supportive attitude towards one of the two main political parties in Poland, which 
are: Law and Justice (Prawo i Sprawiedliwość: right-wing, conservative, national) and Civic Platform (Platforma Obywatelska: centre-right, liberal-conservative). A typical feature of the Polish media market is also the high degree of ownership concentration and domination of German corporations. However, the dominance of foreign capital does not refer to the opinion weeklies market in Poland, which was controlled by Polish capital.

The weeklies selected for the analysis have different political affiliations, as well as different histories. The oldest of the magazines is Gość Niedzielny. The first issue of this Catholic weekly was published on 9th September 1923 and has been associated with the Metropolitan Curia in Katowice since its beginning. The subject matter presented in the magazine is related to its publisher. It publishes articles dealing with faith, the life of the Church, social and economic analyses, presentation of scientific and cultural issues (Gość Niedzielny, WWW). Due to its history and the publisher, this title is identified with the right wing of the political scene in Poland. In the group of the weekly magazines selected for the analysis, right-wing affiliations are also attributed to three other titles: Gazeta Polska (right-wing conservative profile), W Sieci and Do Rzeczy (both are conservative-liberal).

The last two magazines were created due to a conflict within the previously existing rightwing, conservative weekly Uważam Rze, as a result of which some journalists were made redundant and some of them left the magazine themselves. W Sieci and Do Rzeczy present an editorial policy related to Law and Justice (PiS); moreover, these magazines are characterised by the so-called identity journalism, whose main task is "not to inform, but to integrate and mobilise supporters of a particular political option”. (Brzoza, Kornacka-Grzonka, 2017, 115). What is interesting, both titles compete with each other for the interest of readers and treat each other as competitive magazines.

The first issue of W Sieci $^{5}$ was published on 26th November 2012 and the publisher of the magazine was the Fratria company. From the very beginning, the magazine held a stand in opposition to the Civic Platform, which was in power at that time. According to the declaration of the editor-in-chief, Jacek Karnowski, W Sieci was to be an alternative to mainstream media, which

\footnotetext{
5 The magazine was published with the title W Sieci until 2017. The change of the name to Sieci was forced by a litigation over the rights to the title with the Spółka Gremi Media company. In the references and in the article, the title from 2016 is used.
} 
presented reality selectively. As he pointed out, the magazine was supposed to be a forum for exchanging opinions and a place for disclosing true information (Karnowski, 2012, 3). The weekly's distinctive feature were interviews with "representatives of ideological and political groups connected with Law and Justice”. ( Mielczarek, 2018, 69). A constant tendency was also to present social reality in a dichotomous way, in reference to the division into supporters and opponents of Law and Justice.

Do Rzeczy appeared on the Polish media market on 25th January 2013. Its publisher is the Polish Orle Pióro company. The editor-in-chief of the magazine, Paweł Lisicki, declared that the magazine was non-partisan and independent of politicians. Despite these declarations, the weekly is associated with the Law and Justice party. Politics is an area of special importance for the editorial board (Brzoza, Głuszek-Szafraniec, Szostok, 2017, 105), the journalistic materials concerning it are politicised and contain an unambiguous vision of the world and an assessment of reality. Journalists refer to the Christian tradition and emphasize the importance of economic freedom.

Gazeta Polska has a right-wing conservative profile. This weekly, established in March 1993, has made itself stand out on the Polish media market thanks to the creation of Gazeta Polska Clubs (Kluby Gazety Polskiej) all over Poland. They are local discussion clubs, which organise meetings with right-wing journalists, politicians and writers, as well as film showings. The clubs activate right-wing communities; this was evidenced, for example, by the monthly marches commemorating the Smolensk disaster of 2010, in which, among others, the President of Poland was killed. The reality presented by the magazine is one-dimensional, clearly excluding acceptance of different standpoints. Stanisław Pamuła described the weekly as "national, independence and patriotic; spreading Catholicism and fighting against the remnants of communism”. (Pamuła, 1996, 105-106). Gazeta Polska is published by Niezależne Wydawnictwo Polskie.

On the other side of the political spectrum there are two weeklies: Polityka and Newsweek Polska. The first one has a longer history. Its first issue was published on 27th February 1957. The magazine was under the control of the Polish United Workers' Party (PZPR). Polityka gained independence from the party in 1990. It was then that the publisher became Spółdzielnia Pracy Polityka, and since 2012 the magazine has been published by a joint-stock limited company. Polityka's profile is liberal-left (Zuba, 2012, 307-308). In the second decade of the 21st century, the weekly opted for the Civic Platform (Mielczarek, 2013, 88). This magazine also tries to 
maintain constant contact with its readers. For this purpose, it organises Salony Polityki, which are open meetings with important figures and readers.

Newsweek Polska was first published on 3rd September 2001 by the German Axel Springer corporation. Since 2012, its editor-in-chief has been the well-known Polish journalist Tomasz Lis. This is one of the Polish weeklies which runs intensive promotional campaigns and tries to attract readers through supplements such as films or binders. Among other titles, it is distinguished by a higher proportion of graphic elements and photographs, as well as shorter texts; this is dictated primarily by the preferences of its readers, who are much younger than in the case of the other analysed magazines. Newsweek has unequivocal political affiliations: it is unquestionably against Law and Justice, which is regarded by the magazine as authoritarianism and a threat to the development of Poland and its international position (Brzoza, Głuszek-Szafraniec, Szostok, 2017, 102). Newsweek supports Civic Platform.

The interest of recipients in printed media in Poland is systematically decreasing, which was reflected in the decline in circulation and sales, including opinion weeklies (Table 2). In 2018, readers were most willing to reach for Gość Niedzielny (sale of 112,659 copies), published by the Polish Instytut Gość Media company. The sales of Polityka and Newsweek did not exceed 100,000 copies. The remaining opinion weeklies distributed less than 50,000 copies.

Table 2: Average one-time circulation and sales of opinion weeklies in Poland

\begin{tabular}{|c|c|c|c|c|c|c|c|c|}
\hline & \multicolumn{2}{|c|}{2015} & \multicolumn{2}{|c|}{2016} & \multicolumn{2}{|c|}{2017} & \multicolumn{2}{|c|}{2018} \\
\hline Title & $\begin{array}{l}\text { Average } \\
\text { circulation }\end{array}$ & Sales & $\begin{array}{l}\text { Average } \\
\text { circulation }\end{array}$ & Sales & $\begin{array}{l}\text { Average } \\
\text { circulation }\end{array}$ & Sales & $\begin{array}{l}\text { Average } \\
\text { circulation }\end{array}$ & Sales \\
\hline $\begin{array}{l}\text { Gość } \\
\text { Niedzielny }\end{array}$ & 203779 & $\begin{array}{l}134 \\
025\end{array}$ & 189811 & $\begin{array}{l}130 \\
269\end{array}$ & 185105 & $\begin{array}{l}123 \\
450\end{array}$ & 177695 & 112659 \\
\hline Polityka & 171516 & $\begin{array}{l}118 \\
949\end{array}$ & 172197 & $\begin{array}{l}118 \\
419\end{array}$ & 166268 & $\begin{array}{l}109 \\
105\end{array}$ & 145196 & 97436 \\
\hline $\begin{array}{l}\text { Newsweek } \\
\text { Polska }\end{array}$ & 184814 & 120576 & 175687 & $\begin{array}{l}112 \\
113\end{array}$ & 158027 & 96822 & 139167 & 85357 \\
\hline W Sieci & 149677 & 76134 & 147468 & 71536 & 135046 & 61836 & 108766 & 44215 \\
\hline Do Rzeczy & 119305 & 55265 & 112856 & 53166 & 107526 & 42163 & 90861 & 34519 \\
\hline
\end{tabular}




\begin{tabular}{|l|l|l|l|l|l|l|l|l|}
\hline $\begin{array}{l}\text { Gazeta } \\
\text { Polska }\end{array}$ & 103744 & 37549 & 97542 & 35225 & 110671 & 34289 & 101682 & 26854 \\
\hline
\end{tabular}

Source: Author's compilation based on data from Związek Kontroli Dystrybucji Prasy

(Union of Press Distribution Control - ZKDP) for the years 2015-2018.

\section{The causes of Brexit indicated by the weeklies}

The answer to the research question concerning the way of presenting the potential consequences of Brexit in the analysed weeklies required the identification of recurring topics in journalistic materials. All the editors claimed that the reasons for Brexit were as follows:

- $\quad$ David Cameron's declaration;

- $\quad$ British mentality and the difference between Great Britain and Continental Europe;

- $\quad$ reluctance towards the inflow of migrants, especially from the new EU member states (Poland);

- $\quad$ the specific nature of the European Union (bureaucracy, enforcing common rules);

- $\quad$ the attitude of the British to sovereignty.

A referendum on the future of Great Britain in the European Union was carried out in connection with Prime Minister David Cameron's declaration made in the campaign before the parliamentary elections in 2015. It was intended to help "control the party and silence the Eurosceptics in its own ranks" (Zla fala, 2016, p. 14) and weaken the competition from the Office of Competition and Consumer Protection of Nigel Farage (Bault, 2016a, p. 78). This assessment was shared by the authors of all the analysed papers. They agreed that the internal dispute in the Tory party was transformed into conflict, "which the whole of Europe had to deal with" (Rokita, 2016b, p. 70) and the member states became its hostages (Szostkiewicz, 2016, p. 8). Cameron has for the sake of domestic politics, , arranged a great international spectacle, blackmailing the whole of Europe with the fact that if it does not give him support now, England will begin the process of demolition and decomposition of the internal EU" (Rokita, 2016b, p. 70).

All editors agreed that the decision to vote for leaving the EU was influenced by the mentality of the British and the dissimilarity of Great Britain from continental Europe, from which it differs in "almost everything: from the system of measurements, direction of the road, power 
sockets to the understanding of law and parliamentarism, as well as the role that individual states play in a united Europe" (Dziedzina, 2016d).

Newsweek was the title highlighting this issue. For example, in an interview Radosław Sikorski noticed that British politicians, even pro-European, distanced themselves from the Union: "they did not talk about the EU as we, only as they and acted on the international arena with regard to national policy only" (Zla fala, 2016, p. 14). Also ordinary citizens did not feel European, they did not have the sense of belonging to the EU and did not have knowledge ("any idea") about it, they did not understand this project (Piwo wygrało, 2016, p. 23) and they preferred to ,"live in an English way” (Anglicy nie sa baranami, 2016, p. 24). The British ,,considered the idea of even closer integration utopian and ridiculous" (Katastrofa w cieniu, 2016, p. 24). According to the articles, the British long for the time when their state was an important player on the international arena and think that the way to regaining its former splendour is to shed , the $E U$ yoke” (Nowicki, 2016), in accordance with the principle of ,, Commonwealth against the European Union" (Piwo wygrało, 2016, p. 23).

This assessment is also similar to the one contained in the Polityka publications. It pointed out that the British reluctance towards the EU results not only from nostalgia for magnificence times, but is related to the fear of losing sovereignty and pounds, ,in exchange for the invasion of metric measures and weights". In the opinion of Marek Ostrowski, this allows the statement that the British ,, are born with some existential distrust of the continent” (Ostrowski, 2016, p. 14) they never considered themselves ,part of Europe, but its neighbour” (Ostrowski, 2015, p. 55). Only on the pages of this title before the referendum the opinion could be found that, paradoxically, common sense in public life will persuade the British to stay in the EU (Szostkiewicz, 2016, p. 8).

The subject matter was presented in a different way by the editorial offices of Gość Niedzielny, Gazeta Polska, W Sieci and Do Rzeczy. These titles underlined British Euroscepticism, which is ,part of British DNA, a way of thinking about the world and about themselves" (Dziedzina, 2016c). It was assessed that anti-EU attitudes refer to emotions, as opposed to the cold calculation of supporters of integration. That is why ,nobody will run to the barricades to fight for Brussels" (Lisicki, 2016a, p. 3). In the opinion of a journalist of Gość Niedzielny, the British had to decide in a referendum whether, ,it pays to continue to pretend to be Europeans, or if they prefer to become what they really are: the British” (Dziedzina, 2016c. See also: Karnowski, 2016c, p. 17; Bender, 2016, p. 14). 
In the opinion of some editors, social processes influenced the results of the referendum. Tomasz Lis in Newsweek argued that one of them consisted in a rebellion against the elite and mainstream. The accumulation of bad emotions towards the elite - disappointment, frustration was treated as a time bomb, a threat greater than the Islamic state or immigrants. He sought negative reasons in social inequalities, populism, xenophobia and nationalism (Lis, 2016c, p. 3). A similar opinion was formulated by political scientist Ivan Krastev, for whom the emotions and lack of trust in experts and the government influenced the decision of the British (Kiedy niemożliwe, 2016, p. 20).

This issue was analysed in the pages of the weekly Do Rzeczy, which drew attention to the division of societies into ordinary citizens and the political elite. The former, wanting to "reasonably manage their freedom" (Brexit jest blisko, 2016, p. 96), voted for Brexit because they had "enough of deciding for them and treating ordinary people as disabled, immature children of special care, which are best taken care of by EU commissioners faraway. The times of partiocracy and expertocracy have ended" (Lisicki, 2016a, p. 3) ${ }^{6}$. In Gość Niedzielny this rebellion was identified as the debate on topics important for Europe (Nowak, 2016).

The influx of migrants was one of the most important reasons for Brexit. Some of the weeklies have embedded this topic in a historical context. And so, Gość Niedzielny reminded its readers that "Britain for decades has been after all the destination of immigration from countries that were once British colonies” (Dziedzina, 2016a). In Polityka, however, attention was drawn to the fact that the unwillingness to immigrants is nothing new: "When the war was not over by Christmas, British revenge in 1914 hit German immigrants: dachshunds were kicked in the streets, German children's nurses were abused and Beethoven's concerts were cancelled" (Rybarczyk, 2016, p. 49). As assessed in the same text "the British like Dr Jekyll and Mr Hyde alternately received immigrants with open arms and then choked again with their influx" (Rybarczyk, 2016, p. 49).

The reluctance towards immigrants in the opinion of Gazeta Polska resulted from the threat of security: “crime among the Muslim minority is disproportionately high in relation to its number,

\footnotetext{
${ }^{6}$ In another of the texts in the weekly, rebellion against the elites was considered not only a European-wide, but also a global phenomenon (Przybylski, 2016a, p. 20).
} 
and the list of the most dangerous British cities almost exactly matches the list of cities with the largest population of Muslims” (Młynarz, 2016a, p. 23).

In Gazeta Polska and Do Rzeczy, it was also emphasized that the attitude towards immigrants was different in individual social classes: "Hundreds of thousands of people come to the Islands every year. It gets dense, crowded, public services are overloaded. Thanks to this, GDP is growing, the elite and business are enjoying, but ordinary people, especially the less educated, have problems” (Karnowski, 2016c, p. 17).

Typical Dave and Jessica for "failures blame others, for example »immigrants« stealing work" (Młynarz, 2016c, p. 13), they have more contact with immigrants, in connection with the influx of immigrants, it is harder for them to find a job or their earnings are reduced (Wawrzyński, 2016, p. 65).

Jacek Dziedzina in Gość Niedzielny, assessing the attitude towards immigrants, concluded that the restrictions on their inflow would not change anything in the British realities, because "British society is already so multiethnic and multireligious that closing the borders is not able to change it” (Dziedzina, 2016a).

All editors reminded the readers that the fear of immigrants concerns newcomers from the new Member States, also, and even above all, Poles, who, according to the reports, were "yapping" “around the clock” (Piwo wygrało, 2016, p. 23. See also: Bault, 2016a, p. 78, Hołdyńska, 2016, p. 24) and supposed to ,take away work and be lazy burdening the British budget for social welfare" (Przybylski, 2016, p. 25. See also Ostrowski, 2016, p. 14), they "were also the largest group of immigrants in British prisons" (Baczyński, 2016a, p. 6). Polityka pointed out to a paradox - "most of the arguments used in the British debate by the supporters of Brexit are like a mirror reflection of our arguments against the invasion of Pakis; but this time in the role of Pakis we see Poles" (Baczyński, 2016a, p. 6). Focusing reluctance on Poles was explained by the fact that political correctness "does not allow (...) to curse without being racist on migrants from the Third World", in contrast to visitors from the Union, the criticism of whom "is less reprehensible, serves as a smokescreen for the aversion to colourful immigration” (Ostrowski, 2015, p. 55).

Among the reasons for the victory of the supporters of Brexit, some of the weeklies saw the media. This issue was strongly emphasized in Newsweek. One of the experts said that "tabloids have led to Brexit. With the passivity of politicians who did not want to rectify these monstrous 
lies" (Piwo wygrało, 2016, p. 23) ${ }^{7}$. According to the editor-in-chief's opinion, the boulevard press used demagogy, which infected the minds of "millions" and brought the public debate to a spectacle of "wrestling in jelly". The media heated up the emotions and underlined the voice of „those who shout louder, lie more effectively, cheat more efficiently” (Lis, 2016c, p. 3). As a result, the media presented "absurd" allegations against the EU, such as the statement of Boris Johnson, according to which it would "not allow children under the age of eight to blow balloons, it would prohibit the recycling of tea in sachets and demand the standardization of coffins" (Nowicki, 2016). Tomasz Lis stated that even the BBC reduced its role to "pseudo-objective recording of statements without verification of facts and arguments" (Lis, 2016d, p. 2). However, he avoids assessing whether the role of the media was decisive (Lis, 2016c, p. 3).

The impact of the media was also highlighted in Polityka. According to the assessment cited therein, the support of The Sun could have brought half a million votes to Brexit supporters (Wójcik, 2016, p. 13). In the assessment of the title, the influence of the media concerned "average citizens" - "tabloid victims". Ryszard Czarnecki in Do Rzeczy also drew attention to the way information was presented. According to him, the media were tracking and describing EU absurdities, e.g. "banana curvature", but they did not indicate the real reasons for regulations. However, he considered the assignment of guilt to Brexit tabloid as an extreme simplification (Podwójna gra Berlina, 2016, p. 14. See also: Piwo wygrało, 2016, p. 22).

The British animosities to the states determining the operation of EU - Germany and France - could also influence the decision to vote in favour of leaving the EU, according to Gazeta Polska. Wiktor Młynarz argued that the unwillingness to France is understandable and goes back to the disintegration of the Roman Empire. On the other hand, in the case of Germany, world wars play an important role, in particular WW2: "The memory of the battle for Britain and the German bombings of London is still very much alive in society. Many Britons are annoyed by the fact that despite the victory in the war, it is not Britain, but Germany that seems to be playing a leading role in Europe” (Młynarz, 2016a, p. 23). One of the experts, prof. Bernd Lucke, said that France and Germany would recognize themselves as "EU motors", while ignoring the will of other countries. He regarded the impact of Germany on the EU as negative and defined its policy as " $a$

\footnotetext{
7 As an example, the method of presentation of migration flows, in which populist propaganda dominated, was indicated. A similar assessment was presented in Brexit nie jest lekiem na zło, 2016, p. 86.
} 
series of dramatic errors combined with arrogance" (Ten plan to prosta droga, 2016, p. 9). The author of the publication in Gość Niedzielny also drew attention to the position of Germany in the EU. In his opinion, the EU is the "emanation of German interests", which is reflected in the law. He considered this a normal situation, because Germany pays the most to the EU budget (Dziedzina, 2016c).

The specificity of the EU is the reason for the victory of Brexit supporters which was indicated by all editors. Gazeta Polska, Gość Niedzielny, W sieci and also Newsweek emphasized that the EU has nothing in common with the cooperation framework defined at the beginning of integration. The difference is so important that, as was written in Newsweek: "if in 1975 Europe looked like the European Union today, most Britons would certainly not vote for the membership. The English think: »We entered a club, but this club has changed. EEC suited us, and the more integrated Union no longer suits us«.” (Anglicy nie sa baranami, 2016, p. 24).

In the opinion of Jacek Wolski in Gazeta Polska, the level and direction of integration is not in line with the expectations of citizens: "We wanted freedom of travel, trade, cultural exchange, discussion about ideas... We got another Council for Mutual Economic Assistance, with ambitions to regulate all areas of our lives. From the kitchen to the bed. We wanted a world of diversity, we were imposed a unified model born in the minds of modern Euro-politicians, eagerly teaching other countries what democracy and civil liberties are as well as imposing them" (Wolski 2016: 2).

All this makes the EU in the article W Sieci described as an "oppressive utopia", not a community that aims to "facilitate trade, open borders and strengthen security" (Karnowski, 2016b, p. 17). Such EU, instead of ,,being a zone of freedom, prosperity and solidarity” became, in the opinion of the journalist of Gość Niedzielny, "a bureaucratic creation, serving as a tool for stronger domination and for the empowerment of weaker members" (Dziedzina, 2016a) imposing "various solutions, unfavourable for all countries, even the quotas of immigrants" (Jest życie poza Unia, 2016). Similarly, the unwillingness was aroused by the number of ,economically and politically harmful regulations" reaching the "limits of the absurd" and inhibiting the development of the EU and Great Britain (Jest życie poza Unia, 2016. See also: J. Dziedzina, 2016b).

The method of making decisions in the EU was also subject of the critics. Do Rzeczy proves that it limits "the sovereignty of nations and the field of operation of democratically elected 
national authorities" (Bault, 2016b, p. 23) and as a result a system is created in which democracy serves as a facade (Lisicki, 2016a, p. 3). The result of the referendum should be treated as an objection to "the way the current Eurocrats manage the Union" and the "usurpation and arrogance of the European Commission" (Lisicki, 2016a, p. 3) ${ }^{8}$. What is important in this context for Jacek Karnowski was also the lack of legitimacy of the authorities (Karnowski, 2016c, p. 17). In Gość Niedzielny, it was recognized that the EU is "centrally controlled, bureaucratized and undemocratic" (Dziedzina, 2015), which led to the rebellion of the most conscious nations (Dziedzina, 2016c).

In the article in W Sieci Andrzej Zybertowicz has recapitulated allegations against the EU. He estimated that: "The set of the actual principles according to which the Union operates should be supplemented by: elitism, bureaucratism, poor transparency of decision-making processes, democratic deficit, violation of solidarity rules between member countries (see Nord Stream), hegemony of the strongest and perverted tolerance resulting, inter alia, in undermining the deep foundations of culture" (Zybertowicz, 2016, p. 98).

The importance of the sovereignty of states in British political culture was another of the indicated reasons for leaving the EU. In the opinion of W Sieci, the British "love their homeland and want to rule in it alone and sovereignly" (Grzybowska, 2016, p. 91) and the unwillingness to the EU is inscribed in British DNA, which caused the collision of "British culture of sovereignty with the Brussels undemocratic bureaucracy" (Karnowski, 2016c, p. 17).

According to the expert in Newsweek, sovereignty gains importance, because globalization has led to the situation when we do not know "who controls what" (Kiedy niemożliwe, 2016, p. 20 ). British »no « for the EU can strengthen the process of renationalising policy in the region and encourage other Member States to formulate demands for the EU (Lis, 2016a, p. 2). The editor-inchief of the magazine reflects on what sovereignty is and how to define it. He asks rhetorical questions that suggest that it consists in the ability to secure one's own interests while looking for compromises within the community, not in an "absolute independence" (Lis, 2016b, p. 2).

The attitude to the role of nation states in the EU in the assessment of Gazeta Polska is strongly related to the vision of Europe and the values to which it should refer: "Our vision of

\footnotetext{
${ }^{8}$ The responsibility of arrogant bureaucrats is also described by: Karłowicz 2016: 69. See also: Polexitu nie będzie 2016: 16.
} 
Europe means freedom for its inhabitants to travel, work, the freedom of the flow of capital, but without any attempt to dominate and the respect for national identities" (Sakiewicz, 2016, p. 2).

In the pages of Do Rzeczy it was recognized that the British, voting in favour of Brexit, voted for sovereignty, which, despite being ridiculed, did not lose its attractiveness for the citizen (Lisicki, 2016a, p. 3) thinking that "it is necessary to regain our country, free it from the power of Brussels" (Stylińska, 2016, p. 76). As it was proved, the turn towards sovereignty resulted from the wrong actions of Euro-enthusiasts who wanted to deepen cooperation in the EU: ,, The genie has now been released from the bottle, it is already in Europe. And euro-enthusiasts let him out. All these »deepeners«, »wideners« and »accelerators « of the EU - well-paid professional euroenthusiasts and amateurs convinced of the validity of their views. All those creators of the United States of Europe, supporters of driving EU countries into the trap of the common currency, enthusiasts of ever faster dismantling of nation states by taking away from them attributes of the sovereign state by the non-democratic European Commission” (Gabryel, 2016, p. 85).

The author of the above-mentioned article suggests that support for the European project would be different if, in accordance with the suggestions of the Eurorealists, the widening of the cooperation was abolished and the nation states were not marginalized. Another author even acknowledges that "Poland has a chance to become the leader of the »eurorealist" camp, i.e. the camp of those who want the European Union to exist, but with greater respect for the sovereignty of nation states” (Bault, 2016b, p. 22). In Gość Niedzielny it was argued that even the most proEuropean British politicians in the 1970s "never wanted to hear about limiting their sovereignty, that is, giving essential competence to the Community institutions" (Dziedzina, 2016b). The very possibility of deciding on the future in the EU structures was recognized in the letter as a condition of "independence” (Nowak, 2016).

The analysis of the reasons for Brexit indicated by the editorial boards led to the identification of a catalogue of five reasons, appearing in all the weeklies. These included David Cameron's declaration, the mentality of the British and the distinctiveness of Great Britain, reluctance towards the inflow of migrants, the specific nature of the EU and the attitude of the British people towards sovereignty. Each of the editors ranked the above issues differently. For example, the attitude of the British towards sovereignty and negative opinion on the specific nature of the EU were highlighted in right-wing magazines (Gazeta Polska, Gość Niedzielny, Do Rzeczy, W Sieci). Additionally, in these magazines attention was drawn to the issues of animosity between 
Great Britain as opposed to Germany and France, which, according to the editorial board's judgement, could have an impact on the result of the referendum. In the case of those weeklies which share their world view with Civic Platform, the issue of mutual animosities of the member states was not raised in the context of Brexit. These magazines considered the British media as "complicit" in Brexit (Polityka, Newsweek).

\section{The consequences of Brexit predicted by the editorial offices}

All editors answered the question concerning the consequences of Brexit ${ }^{9}$. Among the common catalogue of expected consequences, they indicated: a change in the balance of power on the international arena, including the strengthening of Russia's position; a change in Poland's situation in Europe; and potential consequences for the EU itself.

The most important consisted in the change in Russia's position in the international arena and the attitude of that country to the result of the referendum. This issue was strongly emphasized by Gazeta Polska. One of the texts stressed that the UK's stay in the EU would secure the interests of the Member States: "Divide et impera - it has been known for a long time that Putin has taken this maxim to heart. And although the Union is a very flawed organization that is not always heading in the right direction, a united Europe can oppose Russia's imperial attempts more easily than individual states which a politician as effective as Putin can easily play upon” (Młynarz, 2016a, p. 23).

It was estimated that the EU and the United Kingdom guaranteed sanctions against Russia and Brexit could make the organization more pro-Russian (Młynarz, 2016b, p. 19) ${ }^{10}$.

Tomasz Lis in Newsweek, on the other hand, assessed that if the UK were to leave the EU, "all nationalists, populists and putinists in Europe would be satisfied. Anyone supports the Brexit supporters more than the Russian president" (Lis, 2016b, p. 2). Radosław Sikorski in an interview for the same title stated that „, President Putin just dreamed about it - to be able to play European countries one by one and not negotiate with us as a whole”. Russia, in his opinion, treats Brexit as a "rematch for the collapse of the USSR" (Zla fala, 2016, p. 16).

\footnotetext{
${ }^{9}$ The study deliberately omits the effects of Brexit for Great Britain, due to the lack of differences in the way they are presented in the analysed writings.

${ }^{10}$ A similar assessment was presented in Czarnecki 2016: 19.
} 
In W Sieci, UK's exit from the EU was described as an event threatening European unity and "strengthening Russia's position. Because the potential difference between Moscow and individual European countries is greater than between Russia and the sum of these countries" (Skwieciński, 2016, p. 3). Bronisław Wildstein, despite the criticism of the EU, considered it " $a$ centre of resistance against Moscow's imperial tendencies” (Wildstein, 2016, p. 27).

"Putin's Russia" together with nationalists in the EU work together to "lead to the breakup of the Union”, argued Adam Szostkiewicz in Polityka. In the journalist's opinion, Russia takes these actions despite the fact that "the collapse of the Union makes Europe weaker because it puts it to the grip of national egoisms", which led to two world wars. The Union for the journalist is "a guarantee of peace, democracy and development” (Szostkiewicz, 2016, p. 8).

An assessment of relations with Russia is slightly different in the Gość Niedzielny. "Moscow perfectly plays intra-EU divisions and the breakup of the Union would be the most wonderful gift for it", but it was recognized that the EU does not guarantee any protection: "Does the European Union in any way - except for temporary and minor sanctions - threaten the interests of Russia? On the contrary, the construction of the second branch of the Nord Stream gas pipeline has shown that Russia can get along with Western Europe over the interests of the Central European community members." (Dziedzina, 2016d).

The position of Germany in the EU was another of the themes related to the situation on the international scene. In two of the analysed weeklies, the possible increase in their importance was assessed negatively. In Gazeta Polska, it was recognized that "Berlin will want to close Europe and destroy nation-states" (Sakiewicz, 2016, p. 2), striving to strengthen its position (Młynarz, 2016c, p. 13). This concept will not be conducted, which was assessed positively: "I am not afraid of »Carolingian Europe«, a great Germany with a French sidekick. This project is dying before our eyes. And very good!" (Wolski, 2016, p. 2) Germany's policy will only lead to further EU crises.

In the opinion of Jan Rokita in W Sieci, Brexit will make the EU “more German", which will be more important for the future of Europe than financial issues or the influx of immigrants (Rokita 2016a, p. 85). The exit from the EU of Great Britain was seen as the next phase of "integration that turns out to be the path to German hegemony". Other Member States will not agree to this scenario, which may lead to the collapse of the European project (Wildstein 2016, p. 27). Another scenario was presented by Grzegorz Kostrzewa-Zorbas, for whom the United 
Kingdom constituted a counterbalance for Germany and France and without it the founding countries would strengthen the leadership and "return to the project of building a common federal state forever" (Kostrzewa-Zorbas, 2016, p. 19). The opinion regarding the growth of the role of Germany in the EU in the magazine is not the only one. Jan Rokita recognized that in the case of Brexit, it would be "Latin America rather than Berlin that would force its vision of the European order" (Rokita, 2015, p. 92).

Brexit will lead to a change in the European Union and will also re-define Poland's position. This issue was dealt with by all editors, particularly accented in the pages of W Sieci, Do Rzeczy and Polityka.

Ryszard Legutko in W Sieci stated that Brexit will be a historic opportunity for Poland, it will also increase our country's responsibility for the future of the EU (Polexitu nie będzie, 2016: 16). The article Polska ofensywa also mentioned it. Its author, Bronisław Janecki, argued that Poland would become "the second largest and strongest member state that opposes the evolution of the community towards a superstate". Thus it will be the successor of Great Britain in the EU (Janecki, 2016: 22). Poland will have the opportunity to counteract "federalist, German-French tendencies" (Wildstein, 2016, p. 27).

In turn, in the opinion of Ryszard Czarnecki, who gave the interview to Do Rzeczy, this opportunity is connected with the possibility of reforming the EU. MEP agreed that only one concept is right - the one of Jaroslaw Kaczynski, "who has the courage to propose concrete changes and fight for a greater influence of Poland on EU policy, every Pole in charge of national interest will choose the PiS leader. Today, together with Kaczyński, we cannot refuse responsibility for fighting for the Polish cause on the international arena and for influencing the shape of Europe that would make of the EU a structure much closer to the Europe of the Nations than one federal superstate" (Podwójna gra Berlina, 2016, p. 18).

Matthew Tyrmand treats Britain's exit from the EU as a chance as well. In his opinion, Poland should build geopolitical alliances with the Baltic states and the countries of Central and Eastern Europe. Then the "idea of Intermarum has a chance to finally blossom thanks to the EU shock therapy" (Tyrmand, 2016, p. 98. See also: Nowak, 2016). This concept is not shared by the editor-in-chief Paweł Lisicki, for whom "the tales in which now Poland is promoted to the role of the European leader sound little serious" (Lisicki, 2016b, p. 3). 
The critical assessment of the situation of Poland after Brexit was included in the Polityka publications. Even before the referendum many journalists warned that Poland would remain outside the mainstream, almost like Belarus: "We will find ourselves in a situation that we wanted to avoid and we should always be afraid: neither with the West nor with Russia - in a grey area" (Ostrowski, 2016, p. 14). For this reason, and also because of the benefits of EU membership, "cheering on Brexit and dreaming about Europe of sovereign homelands, watching primarily their own national interest, is a historical and geopolitical nonsense” (Baczyński, 2016a, p. 6). Brexit will re-define relations in the European arena, and "Poland, with its increasingly weak position in the Union, would be, unfortunately, among those being aligned rather than aligning” (Baczyński, 2016a, p. 6). A similar assessment in the interview was expressed by Radosław Sikorski: "At the time of the attempt, when the EU will be redefined anew, no one will call Warsaw asking what its idea for the current crisis is" (Zla fala, 2016, p. 16).

The publications in Gazeta Polska also treated on the position of Poland. It was pointed out that Brexit on the one hand would mean an increase in the importance of the "Paris-BerlinBrussels axis" at the expense of the Visegrad Group (Młynarz, 2016c, p. 13), on the other "it could be a chance for Poland to be an important EU country, a partner of the US and Great Britain and an integrator of Central Europe” (Sakiewicz, 2016, p. 2).

What does Britain mean for the EU itself? This question is answered by all of the analysed weeklies. In Gazeta Polska, it was assessed that if the option to leave the EU wins, "the old continent will be in great trouble", and only shock therapy can save it, otherwise "the new migration of peoples will plunge it into the darkness of the Islamic Middle Ages” (Wolski, 2016, p. 2). The combat metaphor also appears in another of the texts: "Paraphrasing Churchill - the battle for Britain is almost over, the battle for Europe begins” (Młynarz, 2016c, p. 13). The article also points to EU budget issues - the exit of the United Kingdom may mean "reduction of EU spending, which will only strengthen EU opponents, or more spending on the common budget" (Młynarz, 2016c, p. 13).

In Newsweek it was noted that Brexit may initiate further cracks in the structure, and "eventually the whole project may collapse". The editor-in-chief concludes that the EU will seek rescue in the so-called "escaping forward" or accelerated integration (Lis, 2016a, p. 2). According to the concept presented in the magazine, Brexit is another crisis situation in the EU, which will check the ability of this organization to adapt and survive: "EU legitimacy will no longer depend, 
for example, on whether it is democratic enough, or whether it has the ability to survive. People believe in their nation-states because they have endured countless storms throughout the centuries. And if the Union succeeds, they will believe in it. As Rainer Maria Rilke wrote: »Who speaks of victory? To endure is all «” (Kiedy niemożliwe, 2016, p. 20).

In the interview Iwan Krastew notes that Brexit is also done in the minds of people. Brexit will have not only economic or institutional, but also psychological consequences.

For the editor-in-chief of Do Rzeczy, Brexit does not entail a return "to the idea of sovereign states", but it will lead to "tightening the screw" and "faster integration", centralization of the EU and limiting the role of nation states (Lisicki, 2016a, p. 3). He describes this as "putting out fire with gasoline", because despite the British opposition to the "ubiquity and guardianship of the Union, the Union responds: we will control even more, we will leave even less liberty" (Lisicki 2016b, p. 3). A similar opinion was formulated by Ryszard Legutko - "the idea of putting the pedal to of centralization, federalization and unanimity to the metal will win after Brexit" (Polexitu nie będzie, 2016, p. 16). Attention was also drawn to the fact that EU actions - limiting the role of nation states, a large number of regulations, too fast integration - threaten the existence of the Union (Gabryel, 2016, p. 85). Brexit, however, may be an impulse "for internal reform, because the Union with the current elites, those who mock the »will of the people ", will either reform or cease to exist" (Tyrmand, 2016, p. 95). Czarnecki assessed the situation similarly. He drew attention to the possibility of establishing in the EU structures "the top of the richest countries, which will get rid of ballast, such as Poland, and will not have to »die for Gdańsk«, which means in the new formula »pay for the metro in Warsaw«. It may repay in the short term, but it will be a spectacular end to European solidarity, which was the foundation of the European Coal and Steel Community, and later the EEC. I believe that Robert Schuman and Alcide De Gasperi would be devastated if they saw what we are doing today with their heritage" (Podwójna gra Berlina, 2016, p. 20).

For Jacek Przybylski, the EU reform after Brexit will ensure not only the survival of the organization, but also its strengthening (Przybylski, 2016a, p. 19). We can deal with such a scenario, when, as the other author proves, proposals of Kaczyński for the reform of the treaties are implemented, which are "the most realistic and constructive after the British decision, because they take into account the will of the majority of European societies” (Bault, 2016b, p. 23). This opinion is shared by Czarnecki (Podwójna gra Berlina, 2016, p. 20). 
Similar opinions are formulated in W Sieci. And here it was pointed out that the EU reform could be an answer to Brexit (Janecki, 2016, p. 22) but it underlined first and foremost "escape forward" or tightening cooperation "towards a super-state focused around the western core" (Karnowski, 2016a, p. 3). The evaluation of such an integration scenario is not unambiguous in the weekly. Kostrzewa-Zorba recognized that "no loose set of countries - if the EU were to be transformed instead of closer integration - would not be able to provide lasting peace" (Kostrzewa-Zorbas, 2016, p. 20). Piotr Skwieciński, on the other hand, assesses negatively "escape forward" by speeding up the integration of the "hard core" as it would "de facto push out the countries from the core (...) it would also mean disintegration (because in the core countries Eurosceptic moods are growing up as well) and tightening an idealized corset demystified by Brexit for a moment” (Skwieciński, 2016, p. 3). Dariusz Karłowicz expresses similar assumptions. In his opinion, "Brexit is a real spectre of the beginning of the end of the entire European project” (Karłowicz, 2016, p. 69). Such a pessimistic vision is not shared in the interview by Professor Robert Geyer. Brexit is not enough for him to cause the breakup of the EU: "For the EU to collapse, much more than Brexit would have to happen - a sharp resumption of the immigration crisis combined with the financial crisis and the breakup of the eurozone" (Brexit nie jest lekiem, 2016, p. 87).

Also, the journalists of Gość Niedzielny point to possible changes in the EU. According to Jacek Dziedzina, the EU will strive to strengthen cooperation, centralization, increase bureaucracy and limit the role of states. These actions are negative, because they mean "deepening all that inevitably leads to the breakup of the European Union” (Dziedzina, 2016a). The same author in another text suggests that the EU can survive "in the shape that Brexit supporters suggest: a loose union of closely cooperating states" (Dziedzina, 2016d).

The future of the EU after Brexit was also considered in Polityka. Jerzy Baczyński, for example, said that the scenarios "extend today between the complete dissolution of the Union and the breakdown into segments of varying degrees of integration” (Baczyński, 2016b, p. 6). The same author in another text considers the second scenario more likely: "The European Union has a lot of flaws and weaknesses, but the answer to most of the crises that are upsetting it (from the debt crisis, climate crisis to immigration crisis) consists in rather more than less of the Union; better coordination and cooperation than competition for egoisms" (Baczyński, 2016a, p. 6). The justification for choosing this alternative is found in the Polexit article. Marek Ostrowski drew 
attention to the fact that anti-EU trends can be observed in Poland, in Romania and Bulgaria, which reinforces the view that the core of the Union can function much better without burdens. Brexit will only "accelerate the political integration of the European Monetary Union (EMU), one of the foundations of the EU". As a result, Brexit will not make everything collapse "like a house of cards. The core of the Union will behave like an anti-seismic construction. Edges will collapse” (Ostrowski, 2016, p. 14).

The potential consequences of Brexit indicated by all the analysed weeklies included a change in the balance of power on the international arena, a change in Poland's situation in Europe and potential consequences for the EU itself. The editors agreed that Brexit would mean strengthening Russia's position on the international arena, which could pose a threat to Poland and Europe. The magazines also assessed the situation of the EU after Brexit in a similar way. They suggested that the British decision would force a reform of the EU. Various scenarios were presented in the weeklies, such as closer cooperation between the old member states, segmental integration, or even the disintegration of the EU. The editors, on the other hand, had different opinions on the situation of Poland after Brexit. The weeklies affiliated to the Law and Justice party (Do Rzeczy, Gazeta Polska, Gość Niedzielny W Sieci,) believed it could (although not unambiguously) strengthen Poland's position in the EU structures. In the case of the magazines supporting Civic Platform, Poland's situation on the European arena after Brexit was clearly assessed as negative. Polityka and Newsweek claimed that it would deteriorate due to the need to reform the European institutions and strengthen cooperation, leading to the marginalisation of the position of the new member states, including Poland.

\section{Acceptance vs. Rejection - the attitude of the magazines towards Brexit}

The evaluation of the referendum result was included in all the weeklies. As a result of the content analysis, it was found that there were significant differences in the assessment of Brexit by each editorial board.

The evaluation of the referendum result was included in all weeklies. A positive attitude towards the decision of the British to leave the EU was expressed in Gazeta Polska. The article of Marcin Wolski was dedicated to them. He stated that "June 24 for the great day of the victory of reason over political correctness and the nation state over the leftist utopia" (Wolski, 2016, p. 2). In his view, the British "unmasked a great fraud" - the European Union. The British »no« is a 
signal of changes in European and global politics, opposition to the current vision of the EU: "The world is waking up. Of course, not everyone will like the daybreak with the face of Nigel Farage, Donald Trump or Marine le Pen, but I prefer this face rather than the round, seemingly inexpressive faces of various eurojerks, completely unnecessary Brussels leeches, preying on the free nations of our continent" (Wolski, 2016, p. 2).

Brexit may also have negative consequences - easing sanctions against Russia and warming EU-Russia relations (Młynarz, 2016b, p. 19) ${ }^{11}$.

The result of the British referendum ,"is the end of Europe as we know it" (Przybylski, 2016a, p. 18), notes Jacek Przybylski on the pages of Do Rzeczy. According to Paweł Lisicki, the British «no» for the EU was not a hasty and ill-conceived decision (Lisicki, 2016a, p. 3) and the exit of Great Britain from the EU is associated with the limitation of sovereignty: "The attempt to unify by force may end with the disintegration of the entire EU organism. Not only is the British not consenting to it, but it is also becoming increasingly clear that such integration by force meets the resistance of an increasing number of Europeans" (Lisicki, 2016b, p. 3).

"Brexit is not the end of the world" - argues Jacek Dziedzina on the pages of Gość Niedzielny. The EU project "has become a caricature of itself", which has discouraged the British (Dziedzina, 2016a). Andrzej Nowak assesses this issue in a similar way, he encourages "reflection on the positive meaning of the British example”. As he claims, when the EU does not respond to the needs of its members "then calls for a change are appropriate and if it does not change-for secession (...) It will either help to repair this more and more ill Union, or the next secessions, and even (God forbid!) the Civil War will be inevitable" (Nowak, 2016).

In $W$ Sieci weekly the assessments of the referendum result are not expressed directly, but in the context of the sovereignty and the status of Poland in the EU. Jacek Karnowski recognized that "the British have changed the course of history again. They are a truly sovereign nation." (Karnowski, 2016c, p. 17). On the other hand, Michał Karnowski assessed that the project was rejected as a "socialist” utopia (Karnowski, 2016b, p. 17). For Bronisław Wildstein, the decision of the British means not only changes in the EU, but also opportunities for Poland (Wildstein, 2016, p. 27. See Reszczyński, 2016, p. 67).

\footnotetext{
${ }^{11}$ A similar assessment was presented in Czarnecki 2016: 19.
} 
Newsweek and Polityka assess Brexit unambiguously negatively, which may be testified by the cover of the first of the weeklies No. 27/2016 entitled Great Fear. For the editor-in-chief of Newsweek, Tomasz Lis, Brexit is the entering of the World, Europe and Poland "in the period of the greatest uncertainty since the Second World War" and the EU itself "may in a moment look like a community of desperates" (Lis, 2016c, p. 2). He criticizes the decision of the British who "acted as if they thought suicide was the best medicine for depression" (Lis, 2016c, p. 2). The topic of Brexit was also taken up by Lis in an editorial to the next issue. He considered the result of the referendum to be ,, the greatest triumph of falsehood, hypocrisy and ordinary stupidity, that led to the victory of lies" (Lis, 2016d, p. 2). These pessimistic assessments were shared by Agata Bielik-Robson, for whom we "stand on the verge of complete chaos" (Piwo wygrało, 2016, p. 23). Jacek Rostowski spoke similarly. For him, Brexit was an act of great collective irresponsibility (Brytyjczycy pożałują, 2016, p. 29). Even before the referendum one of the journalists assessed that "the jump in emptiness is presented as the best of all solutions" (Nowicki, 2016). In the pages of the magazine you can also find calming opinions. One of them was formulated by Adam Zamoyski: "it is not that we jumped out the window. Trains in the tunnel under the English Channel continue to drive. Nobody shoots to the ferries sailing from Calais to Dover. The world will not collapse” (Anglicy nie sa baranami, 2016, p. 24).

In the pages of Polityka before the referendum, hopes were expressed that the British would choose to remain in the EU: "Known is usually better than the unknown. In uncertain times it is better to be together. I believe in the common sense of the British people" (Szostkiewicz, 2016, p. 8). After the failure of the supporters of remaining in the EU, the evaluation could be found in the titles of the articles themselves, e.g. "The end of the world and what next" (Baczyński, 2016b, p. 6), "It was not supposed to be like that". In the latter, Łukasz Wójcik stated that Brexit means the defeat of David Cameron, Great Britain and the EU, but also democracy. In his opinion ,the breakdown of the Union, of which Brexit would be the beginning, according to the hope of the Eurosceptics, would be able to turn our continent into a jumble of football hooligans painted in national colours shaking their batons" (Wójcik, 2016, p. 13).

Political affiliations of the weeklies were reflected in their attitude towards Brexit. Gazeta Polska's publications contained an undeniably positive assessment of Brexit. The other three rightwing titles (W Sieci, Do Rzeczy, Gość Niedzielny) represented a standpoint that could also be 
considered as favourable to Brexit, although not declared expressis verbis. For Polityka and Newsweek (the weeklies close to Civic Platform), Brexit ought not to happen.

\section{Conclusion}

Despite the differences between the various magazines, all the weeklies similarly diagnosed the reasons for the victory of supporters of leaving the European Union. They pointed to Prime Minister Cameron's statements, the mentality of the British, the importance of sovereignty in the British political culture, the influx of immigrants to the United Kingdom, the specificity of the European Union.

The correspondence between the editorial offices concerned the identification of the reasons themselves; however, the assessments and interpretations of the reasons, apart from the first two, were different. For example, in articles pointing to the mentality of the British in Polityka and Newsweek the issues of the lack of membership to the EU and Commonwealth were emphasized, in other weeklies euroscepticism.

Differences were also evident in the description method. For example, the matter of opposition to the mainstream both in Do Rzeczy and in Newsweek was related to emotions or values. In the case of the first of the weeklies, it was joy, freedom and the ability to decide. For Newsweek journalists, however, it meant reluctance, negative attitude or rebellion. A positive presentation can also be found in publications of Do Rzeczy, Gazeta Polska, Gość Niedzielny and W Sieci discussing the importance of sovereignty for the British. In the articles, it was linked to with a system of values, independence and national identity.

The weeklies assessed that European integration looks different than at the beginning. In the case of Do Rzeczy, Gazeta Polska, Gość Niedzielny and W Sieci, the negative consequences of closer integration, such as lack of transparency of EU institutions, overregulation, bureaucracy or lack of legitimacy, were emphasized. In addition, in the case of Gość Niedzielny, the former position of Germany in the EU was analysed more widely.

All correspondents agreed that the inflow of immigrants to Great Britain had a significant impact on the decisions of the British. Similarly, they all noticed that the newcomers were identified with the citizens of the new Member States, including Poles. This last issue was more widely presented in Polityka than in the other magazines. In Gazeta Polska, Do Rzeczy, W Sieci, it was emphasized that the attitude towards immigrants was different in different social classes. 
It is interesting that the difference in the way Brexit's causes are presented by the magazines cannot be reduced to their political affiliations. There is a correlation in exposing the issue of sovereignty and animosity between Great Britain and Germany and France in right-wing magazines (Gazeta Polska, Do Rzeczy, W Sieci), or in the case of the magazines closer to Civic Platform (Polityka, Newsweek), the role of the media in the pre-referendum campaign. However, the catalogue of the reasons of Brexit pointed out by the magazines is very similar. The differences lie primarily in the different rank given by the editors to particular issues.

The effects associated with the UK's exit from the EU were presented in all titles. They included, among others, the change of Russia's position in relations with the EU, the situation of Poland in the EU, the future of the EU.

All editorial offices share the view that Brexit will weaken the position of the EU and its member states in relations with Russia. They likewise emphasized that Russia is interested in such a scenario and is taking steps to implement it. The change of Germany's status in the EU was the subject of deeper reflection in Gazeta Polska and W Sieci. Both editorial offices decided that Brexit would lead to the strengthening of Germany in the EU, both assessed it negatively.

In the case of publications presenting the consequences of Brexit for Poland, the magazines can be divided into three groups. The first, which includes Gazeta Polska, Gość Niedzielny and W Sieci, saw in Brexit the chances for Poland to strengthen its position in the EU. However, Polityka and Newsweek believe that it will not strengthen Poland's position in the EU, Poland will not determine the direction of the organization's development. In the case of Do Rzeczy, the articles contain an ambivalent attitude, some journalists consider Brexit to be an opportunity for Poland, some of them undermine this view.

The analysis of the content also made it possible to see the similarity in the description of the EU's future after Brexit. Editors point out that it means a challenge for Europe. They draw attention to various possible scenarios from the collapse of the European integration project, through the acceleration of integration, the division of the various speeds into the Union to the reform of the organization.

Significant differences between weeklies can be seen in the Brexit assessment. All editors in the articles, describing the results of the referendum, emphasized that it is a danger and a threat. In the case of Gazeta Polska, however, this is only signalled, in the texts the recognition of the British decision prevails. Three of the analysed titles, Do Rzeczy, Gość Niedzielny and W Sieci 
mention the threats related to Brexit, but treat it as a new opening, the possibility of reforming the institution and the way of thinking about the role of the state in the EU and opposition to limiting the sovereignty of Member States. An unambiguously negative assessment of the decision of the British is presented in Polityka and Newsweek. They treat it as ill-conceived, resulting in negative consequences and associated with uncertainty.

The qualitative analysis of the way Brexit was discussed in Polish opinion weeklies in 2015 and 2016 confirmed the link between the assessment of the event in the weeklies and their political affiliations. This correlation can be seen, for example, in the editorial boards' stance towards Brexit, which was positive in right-wing titles (Do Rzeczy, Gazeta Polska, Gość Niedzielny, W Sieci) and negative in the magazines supporting Civic Platform (Polityka, Newsweek). However, no significant differences were found as regards the causes and effects of Brexit identified by the editorial boards. Regardless of political affiliations, journalistic materials indicated the same main reasons and the most important consequences of Britain's leaving the European Union. However, they were hierarchised differently and assigned a different rank.

\section{References}

1. ANGLICY NIE SĄ BARANAMI (2016) with Adam Zamoyskim talked to Jacek Pawlicki, Newsweek, No. 27, pp. 24-26.

2. BACZYŃSKI, J. (2016a) Dwa końce kija, Polityka, No. 26, p. 6.

3. BACZYŃSKI, J. (2016b) Koniec świata i co dalej, Polityka, No. 27, p. 6.

4. BAUlT, O. (2016a) Brexit nic nie da, Do Rzeczy, No. 9, pp. 78-79.

5. BAULT, O. (2016b) Krajobraz po Brexicie, Do Rzeczy, No. 27, p. 21.

6. BENDER, I. (2016) Władaj, Brytanio. Anglików długa droga do wyjścia z UE, Gazeta Polska, No. 26, p. 14.

7. BREXIT JEST BLISKO (2016) Marcin Makowski talked to Matthew Tyrmand, Do Rzeczy, No. 26, p. 96.

8. „BREXIT NIE JEST LEKIEM NA ZŁO” (2016) Aleksandra Rybińska talked to prof. Robertem Geyer. W Sieci, No. 25, pp. 86-87.

9. BRYTYJCZYCY POŻAŁUJĄ TEJ DECYZJI (2016) interview with Jackiem Rostowskim by Radosław Omachel, Newsweek, No. 27, pp. 28-29. 
10. BRZOZA, K., GŁUSZEK-SZAFRANIEC, D., SZOSTOK, P. (2017) Upolitycznienie przekazu prasowego w wybranych polskich tygodnikach opinii. Wstępny raport z badań, Political Preferences, No. 16, pp. 81-106.

11. BRZOZA, K. and KORNACKA-GRZONKA, M. (2017) Narracja medialna wyrażona na okładkach wybranych tygodników opinii podczas parlamentarnej kampanii wyborczej 2015 roku, Polityka i Społeczeństwo, No. 4 (15), pp. 100-116.

12. CZARNECKI, R. (2016) Porzucona Unia, Gazeta Polska, No. 31, p. 19.

13. DOBEK-OSTROWSKA, B. (2015) Między politologią i komunikologią. Razem czy osobno? Przypadek studiów porównawczych nad relacjami polityki i mediów w Europie ŚrodkowoWschodniej, Politeja, No. 36, pp. 27-49.

14. DZIEDZINA, J. (2015) Wyspy odpływają. Gość Niedzielny, [Online] No. 19.

15. DZIEDZINA, J. (2016a) Bitwa o Europę. Gość Niedzielny, [Online] No. 27.

16. DZIEDZINA, J. (2016b) Brytyjczycy szukają wyjścia. Gość Niedzielny, [Online] No. 20.

17. DZIEDZINA, J. (2016c) Być albo nie być. Gość Niedzielny, [Online] No. 26.

18. DZIEDZINA, J. (2016d) To już jest koniec?. Gość Niedzielny, [Online] No. 8.

19. EUROPE DIRECT (2016) Contact Centre EDCC annual activity report for 2016, https.//ec.europa.eu/info/sites/info/files/europe-direct-annual-activity-report-2016_en.pdf (01.12.2017).

20. GABRYEL, P. (2016) Londyn - wina euro entuzjastów, Do Rzeczy, No. 25, p. 85.

21. GOŚĆ NIEDZIELNY NA CZELE SPRZEDAŻY tygodników opinii w I półroczu 2016, 2016, http.//www.wirtualnemedia.pl/artykul/gosc-niedzielny-na-czele-sprzedazy-tygodnikowopinii-w-i-polroczu-2016-wprost-z-najwiekszym-spadkiem.

22. GRZYBOWSKA, K. (2016) Romantyczni jak Brytyjczycy, W Sieci, No. 25, p. 91.

23. HOŁDYŃSKA, E. (2016) Ilu Polaków wróci do kraju, Do Rzeczy, No. 26, pp. 24-25.

24. JANECKI, S. (2016) Polska ofensywa, W Sieci, No. 27, p. 22.

25. JEST ŻYCIE POZA UNIĄ (2016) interview with Andrzejem Sadowskim, Gość Niedzielny, [Online] No. 20.

26. KAFEL, M. (1969) Prasoznawstwo. Warszawa: Państwowe Wydawnictwo Naukowe., 265 pp.

27. KARŁOWICZ, D. (2016) Detonator Camerona, W Sieci, No. 27, p. 69.

28. KARNOWSKI, J. (2012) Na powitanie, W Sieci [Online], No. 1.

29. KARNOWSKI, J. (2016a) Groźny Brexit, W Sieci, No. 23, p. 3. 
30. KARNOWSKI, J. (2016c) Zmienili bieg dziejów, W Sieci, No. 26, p. 17.

31. KARNOWSKI, M. (2016b) Otwiera się pole nowej gry, W Sieci, No. 26, p. 17.

32. KATASTROFA W CIENIU WIELKOŚCI (2016) wywiad z Antonym Beevorem, Newsweek, No. 28, p. 24.

33. KIEDY NIEMOŻLIWE STAJE SIĘ MOŻLIWE (2016) Maciej Nowicki talked to Iwan Krastev, Newsweek, No. 27, pp. 18-20.

34. KOSTRZEWA-ZORBAS, G. (2016) Brexit. wyzwanie dla Europy, W Sieci, No. 26, pp. 1821.

35. LIS, T. (2016a) Co może czekać Unię Europejską po Brexicie? - Wstępniak...., Newsweek, No. 26, p. 2.

36. LIS, T. (2016b) Cud i przekleństwo, Newsweek, No. 26, p. 2.

37. LIS, T. (2016c) Katastrofa europejska, Newsweek, No. 27, pp. 2-3.

38. LIS, T. (2016d) Ostatni dzwon, Newsweek, No. 28, p. 2.

39. LISICKI, P. (2016a) Lud się zbuntował, Do Rzeczy, No. 26, p. 3.

40. LISICKI, P. (2016b) Więcej suwerenności, Do Rzeczy, No. 27, p. 3.

41. MIELCZAREK, T. (2013) Współczesna polska prasa opinii, Rocznik Historii Prasy Polskiej, No. 1 (31), pp. 79-102.

42. MIELCZAREK, T. (2018) „wSieci”: tygodnik opinii czy społeczno--polityczny tabloid?, Rocznik Historii Prasy Polskiej, No. 1 (49), pp. 65-79.

43. MŁYNARZ, W. (2016a) Bitwa o Brytanię, bitwa o Europę, Gazeta Polska, No. 13, p. 23.

44. MŁYNARZ, W. (2016b) Nadciąga Brexit, Gazeta Polska, No. 25, p. 19.

45. MŁYNARZ, W. (2016c) Życie po Brexicie, Gazeta Polska, No. 26, pp. 12-13.

46. MUSIŁ-KARG, M. (2016) Brytyjskie i węgierskie referenda z 2016 r. Uwagi o roli instytucji demokracji bezpośredniej w procesie integracji europejskiej, Przeglad Europejski, No. 3, pp. 78-97.

47. NOWAK, A. (2016) Razem czy osobno, Gość Niedzielny, [Online] No. 26.

48. NOWICKI, M. (2016) Panamski problem Camerona, Newsweek, No. 17, p. 57.

49. OSTROWSKI, M. (2015) Dwie batalie Davida Camerona. Złoty chłopiec, Polityka, No. 1, pp. $55-57$.

50. OSTROWSKI, M. (2016) Polexit, Polityka, No. 19, pp. 12-14. 
51. PAMUŁA, S. (1996) Metoda analizy zawartości prasy i jej zastosowanie w wybranych tygodnikach. Częstochowa: Wydawnictwo Wyższej Szkoły Pedagogicznej w Częstochowie., $160 \mathrm{pp}$.

52. PIWO WYGRAŁO Z WINEM (2016) wywiad z Agatą Bielik-Robson, Newsweek, No. 27, pp. 21-23.

53. PODWÓJNA GRA BERLINA (2016) interview with Ryszard Czarnecki by Marcin Makowski, Do Rzeczy, No. 27, pp. 18-20.

54. POLEXITU NIE BĘDZIE (2016) interview with prof. Ryszardem Legutko by Marcin Makowski, Do Rzeczy, No. 26, pp. 14-16.

55. PRZYBYLSKI, J. (2016a) Cena rozstania, Do Rzeczy, No. 26, pp. 18-20.

56. PRZYBYLSKI, J. (2016b) Jad Brexitu, Do Rzeczy, No. 27, pp. 24-26.

57. RESZCZYŃSKI, W. (2016) Brexit, czyli szansa dla polskiej gospodarki, W Sieci, No. 26, p. 67.

58. Reuters Institute (2017) Digital News Report, https://reutersinstitute.politics.ox.ac.uk/sites/default/files/Digital\%20News\%20Report\%2020 17\%20web_0.pdf.

59. ROKITA, J. (2015) Cameron niezastąpiony, W Sieci, No. 20, pp. 90-92.

60. ROKITA, J. (2016a) Bezradność i lęk, W Sieci, No. 25, pp. 84-85.

61. ROKITA, J. (2016b) „Hazard Camerona, W Sieci, No. 9, pp. 70-72.

62. RYBARCZYK, M. (2016) Mała Brytania, Polityka, No. 51, pp. 48-49.

63. SAKIEWICZ, T. (2016) Bierzmy odpowiedzialność za całą Europę, Gazeta Polska, No. 26, p. 2.

64. SKWIECIŃSKI, P. (2016) Między skałami, W Sieci, No. 27, p. 3.

65. STASIAK-JAZUKIEWICZ, E. (2015) The image of the EU in Polish magazines. Based on the analysis of the contents of "Polityka", "Wprost" and "Newsweek" published in 2013, Przeglad Europejski, No. 1 (38), pp. 68-89.

66. STYLIŃSKA, T. (2016) Efekt domina, Do Rzeczy, No. 27, pp. 76-77.

67. SZOSTKIEWICZ, A. (2016) Po pierwsze, common sense, Polityka, No. 9, p. 8.

68. TEN PLAN TO PROSTA DROGA DO ROZPADU UE (2016) interview with prof. Berndem Lucke by Olga Doleśniuk-Harczuk, Gazeta Polska, No. 26, p. 9.

69. TYRMAND, M. (2016) Europo, pobudka!, Do Rzeczy, No. 27. p. 96. 
70. WAWRZYŃSKI, P. (2016) Wnioski z Brexitu, Do Rzeczy, No. 28, pp. 64-65.

71. WILDSTEIN, B. (2016) Samobójcza strategia euro entuzjastów, W Sieci, No. 27, pp. 25-27.

72. WÓJCIK, Ł. (2016) Nie tak miało być, Polityka, No. 27, p. 13.

73. WOLSKI, M. (2016) Etap prawdy, Gazeta Polska, No. 26, p. 2.

74. ZŁA FALA (2016) the interiew of Agata Pawlicka with Radosław Sikorski, Newsweek, No. 27, p. 14.

75. ZUBA, K. (2012) Polska scena polityczna: ciągłość i zmiana. Warszawa: Wydawnictwo Sejmowe., 362 pp.

76. ZYBERTOWICZ, A. (2016) Zabawa w Pana Boga, W Sieci, No. 27, p. 98. 